\title{
Pre-service teachers' reflective judgment skills in the context of socio-scientific issues based inquiry laboratory course
}

\author{
Dilek Karışan \\ Adnan Menderes University, Faculty of Education, Aydın, Turkey, \\ dilekkarisan@gmail.com,orcid.org/0000-0002-1791-9633 \\ Özgül Yilmaz-Tüzün \\ Middle East Technical University, Faculty of Education, Ankara, Turkey, \\ ozgul@metu.edu.tr, orcid.org/0000-0001-7869-9251 \\ Dana L. Zeidler \\ University of South Florida, Faculty of Education, Tampa, USA, \\ zeidler@usf.edu, orcid.org/0000-0002-4250-4982
}

\begin{abstract}
There are certain threats embedded in scientific development that confront society. Gaining practical and instrumental experiences in addressing topics related to the major challenges that confront society today can be possible by tapping the socio-scientific issues as a part of science teaching and learning. This research aimed to explore pre-service teachers' reflective judgment skills in socioscientific issues based inquiry science laboratory course. The participants of the research were 20 pre-service teachers at a research oriented public university. Qualitative case study research design was used in this study. The laboratory manuals and semi-structured interviews were used as data collection tools. Data were analyzed by using King and Kitchener's (1994) reflective judgment framework. Results of the study showed that pre-service teachers' reflective judgment scores tended to increase from the first experiment to the last experiment. Results suggested that exploring reflective judgment in socio-scientific contexts is beneficial for allowing pre-service teachers to actively engage in knowledge construction.
\end{abstract}

Keywords Reflective judgment, Pre-service teachers, Inquiry, Science laboratory, Socio-scientific issues

\section{Öğretmen adaylarının sosyo-bilimsel konular temelli fen laboratuvarı dersindeki yansitıcı muhakeme becerileri}

ÖZ Toplumların bilim temelli güçlüklerle karşılaşmakta olduğu inkâr edilemez bir gerçekliktir. Bu tür problemlere karşı pratik deneyimler kazanmanın olası yollarından biri derslerde sosyo-bilimsel konulara yer vermektir. Bu çalışmanın amacı öğretmen adaylarının sosyo-bilimsel konular temelli fen laboratuvar uygulamaları dersindeki yansitıcı muhakeme becerilerini incelemektir. Katılımcilar 20 öğretmen adayından oluşmaktadır. Bu çalışmada nitel durum çalışması araştırma yöntemi uygulanmıştır. Yarı-yapılandırılmış mülakatlar ve deney raporları veri toplama aracı olarak kullanılmıştır. Veriler King ve Kitchener (1994) tarafından geliştirilen yansıtıcı muhakeme modeli kullanılarak analiz edilmiştir. Çalışma sonuçlarına göre öğretmen adaylarının Yansıtıcı Muhakeme Modeli puanları birinci deneyden son deneye doğru artma eğilimi göstermiştir. Yansıtıcı muhakeme becerilerinin sosyo-bilimsel konular bağlamında ele alınmasının, öğretmen adayların bilgiyi aktif olarak yapılandırmaları açısından faydalı olduğu bulunmuştur.

\section{Anahtar Kelimeler Yansıtıcı muhakeme, Ö̆gretmen adayı, Araştırma sorgulama, Fen laboratuvarı, Sosyo-bilimsel konular}




\section{INTRODUCTION}

The reach of science and technology extends virtually to every aspect of human life and our associated ecological interactions with the living and non-living world. Students, as citizens in this technology-rich and scientifically complex world, need to know that the world is far more complex than it first appears and need to have practical and instrumental experiences in addressing topics related to the major challenges. Any educational practice focusing solely on the products and application of science willfully ignores the normative formation of scientific ideas, ideals and goals, thereby misrepresenting the human activity of science (Next Generation Science Education Standards [NGSES], 2012). One of the overarching goals of science education is to engage the public in discussions on scientific issues (National Research Council [NRC], 2012) to understand the effects of scientific and technological developments on their everyday lives (Martin-Gámez \& Erduran, 2018; Osborne \& Dillon, 2008) and to ensure that students have some recognition of the beauty and wonder of science (Egan, Cant, \& Judson, 2014; Maulucci, 2010). Gaining practical and instrumental experiences in addressing topics related to the major challenges that confront society today can be possible by tapping the socio-scientific issues (SSI) in a manner that allows students to explore and frame scientific investigations as a way to explore interdependence of science and society (Zeidler, 2014; Zeidler, Sadler, Simmons, \& Howes, 2005).

The goal of science education is to help students to understand societal problems, as well as teaching scientific concepts (Lee \& Grace, 2012; Nielsen, 2012; Zeidler, Herman, Ruzek, Linder, \& Linn, 2013). SSI provides useful context for addressing these concerns and has been found to enhance students' learning of scientific concepts and their application to daily life (Lee, Chang, Choi, Kim, \& Zeidler, 2012; Klosterman \& Sadler, 2010). The SSI movement focuses on letting students to handle sciencebased issues that shape their current world and those which will determine their future world (Sadler, 2004). SSI teaching has been empirically investigated and linked to particular outcomes including facilitating sophisticated argumentation, reflective judgment, informal reasoning, and nature of science understanding (Zeidler \& Sadler, 2008; Zeidler, Sadler, Applebaum \& Callahan 2009). From these results, a reflective judgment should be considered that focuses on the ability of developing students to collect and analyze data and use several sources (Zeidler et al., 2009).

Accordingly, there is a critical need for students to have the ability to read, understand, communicate and engage in such complex issues derived from the interaction of science and technology in sociocultural contexts (Yoonsook, Yoo, Kim, Lee, \& Zeidler, 2016). Given that such issues are openended, contentious, usually evoking moral reasoning and often containing multiple competing solutions to each problem (Sadler 2004; Zeidler, 2014), there is a need to engage students in making defensible judgments about real world complex problems and to make sound arguments for their judgments.

Reflective judgment is a kind of epistemic cognition that includes the recognition of uncertainty (exists about many contemporary scientific issues) to the extent that such issues are embedded in and inextricably linked to sociocultural contexts (Zeidler et al., 2009). Reflective judgment domain involves assumptions of the status of knowledge and evidence about ill-structured problems (King \& Kitchener, 1994; 2004). Used in concert with SSI-related pedagogy, teachers challenge students to justify their claims and the evidence used to back those claims while considering the counter claims and evidence from those of other perspectives.

\section{Rationale for the Study}

Over the last decade, science education researchers have been investigating research topics conducive to promoting SSI-based instruction and epistemological understanding of factors related to issues such as off-shore oil drilling, fracking, cell phones and health, genetically modified foods, gene therapy, 
nuclear power plants, animal research, global warming, and so on (Aydin, 2014; Zeidler, 2014; Zeidler $\&$ Kahn, 2014). While such issues are widely used as teaching units, they are also useful in providing a rich context for argumentation studies and reflective judgment research. Zeidler et al. (2009) utilized SSI as a teaching tool to explore students' epistemological improvement (Zeidler et al., 2009). In that study, socio-moral discourse, argumentation and debate were important elements that transformed earlier and perhaps the traditional method of instruction embedded in scientism into pedagogy oriented to progressive sociocultural views of science education. Students' epistemological development were explored by using measures of reflective judgment.

Many researchers used SSI in science classroom activities (Liu et al., 2011; Kølsto, 2001) to engage students with ill structured issues. In such studies, SSI are typically used as a teaching tool to initiate students' interest, and promote active engagement and personal involvement with issues directly related to students' lives. It should be noted that the practice of SSI teaching generally requires the deliberate use of scientific topics that have moral or ethical implications compelling students to engage in protracted forms of discourse (Evagorou \& Mauriz, 2017).

A significant amount of science education research (Anderson, 2002; Bybee, 2000; Waight \& Abd-ElKhalick, 2011) highlights the importance of "doing science." Active engagement in science includes, among other skills, articulating goals of an investigation, predicting possible outcomes, and planning a course of action that will provide the best evidence to support or refute a claim or proposition. In the US, for example, the NGSS (2013) highlight the importance of students' active participation in the processes of science as they construct newfound knowledge. While the science education literature seems to converge on the importance of inquiry learning environments, where students need to be actively engaged in scientific processes, the practical usage of laboratory investigations often falls short in its execution of inquiry activities that not only require higher order thinking skills, but reflect explicit sociocultural aspects of the nature of science, particularly as they may be expressed in SSI drivencurricula (Cobern et al., 2010; Domin, 1999; Khishfe, 2015). Inquiry, like any other pedagogical approach, may be executed to varying degrees of efficacy, and active learning may not be synonymous with inquiry (Cobern et al. 2010; Kirschner, Sweller, \& Clark, 2006).

Students' being reflective about their source of knowledge has given importance by numerous research (Eş, Mercan, \& Ayas, 2016; Paris \& Ayres, 1994; King \& Kitchener, 1994; MacFarlane, 2001) and these research appreciate the contribution of reflective judgment to students' meaningful learning. However, there is not many research that focuses on reflective judgment in an inquiry oriented science laboratory. This study engaged students in reflective judgment (i.e., epistemological reasoning or reflective reasoning), through their own development of concepts and principles via exploration; in that sense the present study aligns this mode of inquiry with authentic learning experiences. In this study characteristics of inquiry learning such as posing questions tied to real world scenarios, obtaining supporting or conflicting evidence to address those questions, collecting, analyzing and interpreting data, helps the inquirer to construct and take ownership of their own knowledge.

Inquiry learning, therefore, as current study envisions it, shifts learning demands on students to construct knowledge by solving real-world problems (NRC, 2012. Green, Elliot, and Cummins (2004) noted, for example, that real-world problems promoted students' science learning, students' by motivating them to use scientific evidence and reasoning to apply to in solutions of these problems. In fact, the students also found new information that cannot be placed in any scientific journal or in a regional report. Therefore, the study of research can serve as a locus for invention, craft and creativity. This study is designed to provide effective laboratory work that involves more authentic (that is, attracts students to scientific argumentation and reflective judgment) and a student-centered learning environment.

Reflective judgment is seen as a construction that represents the views of people on the knowledge and rationale of knowledge. The model rejects two known assumptions advanced by previous researchers. First, unlike Piaget, the Reflective Judgment (RJM) model does not suggest that cognitive development is best measured by deductive reasoning. The second contradiction was that there is no intercultural 
universality. King and Kitchener (1994) recognize that there is a complex stage of development, rather than a simple stage model of development. They are criticized that it is misleading to characterize individuals who are only "in" or "at" one stage of development. The development of reflective thinking is described as:

... waves across a mixture of stages, where the peak of a wave is the most commonly used set of assumptions. While there is still an observable pattern to the movement between stages, this developmental movement is better described as the changing shape of the wave rather than as a pattern of uniform steps interspersed with plateaus (King, Kitchener, \& Wood, 1994 p. 140).

The logical similarities between the Reflective Judgment Model and the SSI framework have been noted previously (Zeidler et al., 2009). Both of them are associated with ill structured problems and problems that require consideration of different opinions and the ability to analyze these positions.

Both involve ill-structured problems and issues that require consideration of differing opinions, the ability to analyze those positions, the backing claims by evidence to support stances, and the recognition of the role of constructed in consensus building. This investigation was aimed to explore pre-service teachers' reflective judgment skills in SSI based inquiry science laboratory. In this manner, preservice teachers were given the opportunity to investigate aspects of real-life SSI in a laboratory setting. Both are important in addressing and reasoning about ill-structured problems where controversy in varied contexts and differing epistemology understandings come to loggerheads. Simple logic and algorithms will be found wanting where more nuanced yet complex reasoning that taps multiple ways of thinking is required. Hence, the purpose of this investigation was to investigate the nature of reflective judgment as they are displayed in the context of a socio-scientific issues-based inquiry science laboratory course. Varied contextualized SSI were selected to discern how reflective judgment are realized in an authentic inquiry setting. To this end, following research question guided the study:

What are the reflective judgment domains of preservice teachers revealed in SSI based inquiry science laboratory course?

\section{METHODOLOGY}

A qualitative case study research design guided the present research (Merriam, 2009). The study investigates pre-service teachers' reflective judgment skills within its real life context. Current research bounded with 20 pre-service teachers who involved in SSI based inquiry science laboratory course throughout a semester (Stake, 1995).

\section{Participants}

Participants were 20 (19Females, 1Males) pre-service teachers with a mean age of 21 years (ranging from 18-25) attending a research oriented university at the department of elementary science and early childhood education. Most of them were juniors with two exceptions: one student was sophomore taking the course early and another was senior, planning to graduate at the end of the semester. The teacher education program also requires preservice teachers to attend professional development opportunities offered throughout their program. Hence, participants had a number of basic experiences, such as participation in career programs, including seminars, presentations and participation in activities with primary school children in order to enhance their professional development. 


\section{Study Context}

Selected SSI were chosen to be used in tandem with this inquiry science laboratory course to allow researchers to more fully explore the preservice teachers (PT)' reflective judgment. Controversial issues framed by global environmental problems are thought to be reasonably explored in a laboratory setting. More specifically, topics related to food additives, climate change, alternative energy sources, and factors related to the industrial revolution were identified for three main reasons: 1) because of their ubiquity in modern society; 2) their facilitation of classroom discourse and argumentation; and 3) amenable nature of each issue. Throughout the course, preservice teachers were engaged in discussions about the controversial issues and were allowed to consider their own scientific questions, and address those questions through deliberately designed laboratory investigations generated by the preservice teachers themselves.

Each single SSI was covered over a period of two weeks. Preservice teachers met in class twice per week and class time spanned two hours per class. The time during the first week was devoted to discussions surrounding a given SSI. Discussions typically entailed various forms of socio-moral discourse associated with SSI, whereby the pre-service teachers were guided to construct their knowledge about the given SSI as part of a social process during collaborative classroom discussions. Additionally, class discussions were guided in a manner that fostered the development of researchable scientific questions, raised by the preservice teachers themselves, which would next be systematically examined by assigned groups in the laboratory component of class. After the first week discussion for each SSI, the second week was designated for laboratory investigations of key science elements embedded within a given issue. Here, the preservice teachers were able to investigate and explore topics to find verifiable empirical support (or lack of support) for various claims that arose out of the previous discussions. Thus, the laboratory became a learning environment where preservice teachers worked together tackling ill-structured problems connected with each issue.

Over the span of thirteen weeks, course mentors had the responsibility to help their groups prepare presentations and to organize preservice teachers' laboratory reports for each investigation. The mentors' role was not to serve as a final arbitrator who resolved issues of conflict, or become the preeminent voice of authority; rather, their role was to ask probing questions in an attempt to propose their own questions, as well as their positions on issues, and offer support and guidance in their research efforts. Mentors themselves also went through a deliberate mentoring process. The criteria to serve as a mentor required that each had to be a graduate student with a master degree in science education having successfully completed coursework toward their $\mathrm{PhD}$. The role of mentors included leading discussions on particular SSI and providing guidance to preservice teachers for group presentations as well as laboratory investigations (described above). These individuals had exposure to nature of science, laboratory experimental methods, pedagogical content knowledge, issues related to environmental concerns, and a basic understanding of SSI-related goals and strategies. All mentors were graduated from the Department of Elementary Science Education and had similar science backgrounds for their Bachelor of Science degree. Meetings and pre-investigation discussions were held to ensure each mentor had both the background knowledge and pedagogical strategies necessary to assist the SSI based inquiry science laboratory course.

Pre-service teachers conducting experiments utilized basic science process skills such as making observation, making inferences, measurement, communicating, and predicting. For example, they could have observed the effects of acids on plant leaves by using various concentrations of hydrochloric acid and sulfuric acid. Preservice teachers recorded their observations, formed inferences about acid rain effects, and drew possible connections and analogies with climate change. Inferences and predictions needed to be communicated to their peers. After conducting investigations, participants answered openended reflective judgment questions about that issue and engaged in reflective discussion with their peers. 
The laboratory manuals were designed using open inquiry methods to allow pre-service teachers to think about how knowledge construction progressed during their experiments. The particular method ultimately selected for investigation was left up to the pre-service teachers to develop. The course mentors were charged with the responsibility to maintain consistency within investigations, help their groups to prepare presentations, and to aid in the organization of preservice teachers' laboratory reports.

\section{Data Collection and Assessments}

Preservice teachers' written records from laboratory investigations and semi structured interviews were used as data collection tools. Reflective judgment was assessed using the Prototypic Reflective judgment Interview (PRJI) which is a semi-structured interview developed by King and Kitchener $(1994 ; 2004)$ and used as an indicator of epistemological sophistication in other SSI research (Zeidler et al., 2009; Zeidler et al. 2013). The interviewer presented four standard interview scenarios to each participant. Those were followed by seven standard questions aimed at encouraging preservice teachers to formulate a stance on each scenario, as well as a justification for their position.

The preservice teachers were interviewed after they completed the experiments. Interviews were used as an additional data source to triangulate laboratory reports. All the Interviews lasted between twenty to thirty minutes, were audio recorded and transcribed.

The precise organization of the reports, as well as the design of the laboratory investigations, was determined by the preservice teachers; hence, each group developed their own research questions and designed their own investigations in order to address their research questions. While there were suggested procedures, they were free to deviate from those and utilize alternative procedures for their investigations. This helped to promote a constructivist-learning environment. Additionally, to foster individual accountability, each preservice teacher prepared their own unique reports; however, all of them responded to the same standard prototypic reflective judgment interview questions at the end of their reports.

\section{Data Analysis}

Preservice teachers' laboratory reports and interview responses were evaluated by the authors of the study in accordance with the levels of sophistication provided by the King and Kitchener $(1994,2004)$ framework for reflective judgment. According to the framework, there are seven levels contained within three broad developmental stages. Scores from 1 to 3 were categorized as pre-reflective, scores from 4 to 5 were categorized as quasi-reflective, and finally scores from 6 to 7 were categorized as reflective stages. Each student's score was summarized into a three-digit code (e.g., 4-4-5). Each digit was differentially weighted (50\% for the first digit, $30 \%$ for the second, $20 \%$ for the $3^{\text {rd }}$ digit) to reflect the relative proportion of emphasis given to the particular developmental levels. Most of the reflective judgment interview responses were comprised of only one or two predominant stages. However, some preservice teachers reveal a wider array of developmental stage indicators in responses. For example, a pattern of reflective judgment might be 5-4-6, which represents a predominant stage of five reasoning patterns, but some responses at stage four, and even less responses at stage six. The display of three stages (e.g., 4-5-3) occurs much less frequently than a pattern composed of two predominant stages of reasoning (e.g., 4-5-5). Table 1 provides an overview of exemplars used for the coding of reflective judgment developmental domains. 
Table 1

Examples of student responses to the PRJI.

\begin{tabular}{|c|c|c|c|}
\hline $\begin{array}{l}\text { Reflective } \\
\text { judgment } \\
\text { Domains }\end{array}$ & Stages & Preservice teachers' explanation & $\begin{array}{l}\text { Major Characteristics of the } \\
\text { stage }\end{array}$ \\
\hline \multirow{3}{*}{$\begin{array}{l}\text { Pre-reflective } \\
\text { (responses of } \\
\text { student } 1 \text { about } \\
\text { using food } \\
\text { additives) }\end{array}$} & Stage 1 & $\begin{array}{l}\text { I believe that sweeteners are very useful in food industry I } \\
\text { know that it is good for the health of diabetic people }\end{array}$ & $\begin{array}{l}\text { Belief is concrete and single- } \\
\text { category }\end{array}$ \\
\hline & Stage 2 & $\begin{array}{l}\text { My grandmother is diabetic. She uses sweetener. Her doctor } \\
\text { recommended to her to use it. It must be healthy. }\end{array}$ & $\begin{array}{l}\text { Justification by agreement } \\
\text { with authority figure }\end{array}$ \\
\hline & Stage 3 & $\begin{array}{l}\text { I read articles about aspartame and lump sugar content. } \\
\text { Moreover, my friend made a presentation about this topic. On } \\
\text { the other hand, I used it before, and I made observations. In } \\
\text { the video, an expert said that } 1 \text { aspartame }=25 \text { lump sugar. }\end{array}$ & $\begin{array}{l}\text { Right answers are provided by } \\
\text { authority }\end{array}$ \\
\hline \multirow{2}{*}{$\begin{array}{l}\text { Quasi-reflective } \\
\text { (Responses of } \\
\text { student } 7 \text { about } \\
\text { using food } \\
\text { colorings) }\end{array}$} & Stage 4 & $\begin{array}{l}\text { I suspect about this issue (using food colorings). Also, some } \\
\text { researchers about food colorings don't have certain } \\
\text { consequences. Food colorings have not only positive effects } \\
\text { but also negative effects. But, I watched on the TV; some } \\
\text { doctors support that food colorings are artificial, and they } \\
\text { have a negative effect on human health over the long term. } \\
\text { Sometimes doctors can have a bias. I do not know. }\end{array}$ & $\begin{array}{l}\text { Authority is often biased, they } \\
\text { fit the evidence to their beliefs. }\end{array}$ \\
\hline & Stage 5 & $\begin{array}{l}\text { I was working as practicing teacher in early childhood center I } \\
\text { made this experiment. We used green and pink food coloring. } \\
\text {...Children wanted to drink colorful milks instead of regular } \\
\text { milk, according to this experiment; I think that food coloring } \\
\text { is attractive. In addition to this, I do not have an exact idea if } \\
\text { they are dangerous or not. }\end{array}$ & $\begin{array}{l}\text { Understanding that people } \\
\text { cannot know directly, but can } \\
\text { within a context based on } \\
\text { subjective interpretation of } \\
\text { evidence }\end{array}$ \\
\hline \multirow[t]{2}{*}{$\begin{array}{l}\text { Reflective } \\
\text { (Responses of } \\
\text { student } 15 \text { about } \\
\text { climate change } \\
\quad \text { issue) }\end{array}$} & Stage 6 & $\begin{array}{l}\text { I think some scientist exaggerating the climate data. You } \\
\text { know; Al Gore's Nobel prize has been cancelled because his } \\
\text { work was ruled politically biased and containing scientific } \\
\text { errors. But personally, I experience some climate change } \\
\text { problems, there are IPCC data. I think; the climate is changing } \\
\text { but may be this change is a little bit exaggerating. I read lots } \\
\text { of articles; we watched national geographic documentary in } \\
\text { class; there are lots of protocols such as Kyoto. You know the } \\
\text { amount of CO2 increase, sea level rise. I mean; the nature is } \\
\text { unbalanced know. }\end{array}$ & $\begin{array}{l}\text { Knowledge is based on } \\
\text { Information from a variety of } \\
\text { sources }\end{array}$ \\
\hline & Stage 7 & $\begin{array}{l}\text { Last week, we were responsible for presenting this issue } \\
\text { (climate change) in the classroom. Before the presentation, I } \\
\text { was sure about the issue I mean, there is climate change and I } \\
\text { had no suspect. But while researching the issue, I saw there } \\
\text { are cons also. }\end{array}$ & $\begin{array}{l}\text { Subject is involved in } \\
\text { constructing knowledge }\end{array}$ \\
\hline
\end{tabular}

\section{Trustworthiness}

The reliability of the current study was based on Lincoln and Guba (1985). To obtain valid and reliable results, three methods were used: triangulation, checking members and providing a thick description. Interview results triangulated with preservice teachers' laboratory reports. In addition, the researcher triangulation was used to establish interrater reliability. Two researchers evaluated each report in turn and graded documents using an independent reflective judgment framework. The level of agreement between the two researchers was calculated. The interrater reliability is found $90 \%$. Triangulation improved the quality of data analysis and the accuracy of the results. The present study, based on a qualitative paradigm, thus, external validity was not the main task of researchers, but even in qualitative studies there are some issues for increasing external validity, such as transferring research results to another study (Merriam, 2009). The issue of external validity for this research is addressed through thick descriptions of participants, data collection procedures, data collection tools and, finally, data analysis procedures. 


\section{Ethical Considerations}

First, the researchers received permission from the University Ethics Committee. After receiving permission from the ethics committee, each participant was informed about the course content. All of them were explained that there would be no harm or deception. Researchers ensured that the confidentiality of data, voice recordings and laboratory reports would be protected, and preservice teachers' names would not be revealed anywhere. Preservice teachers' real names were not used in anywhere but randomly assigned numbers (Table 2 ).

\section{FINDINGS}

\section{Food Additives Issue}

Food additives were examined by five different groups with five different experiments. The experiments those were conducted at this week were; the effects of food colorings, emulsifiers and stabilizers, and sweeteners. Figure 1 shows the numbers of pre-reflective, quasi-reflective and reflective stages in the food additives experiment. It is clear in the figure that quasi-reflective stages were frequently observed across these experiments. Eleven of the 20 Pre-service teachers' responses fell into the quasi-reflective; six responses were pre-reflective, and three of them were in reflective stages

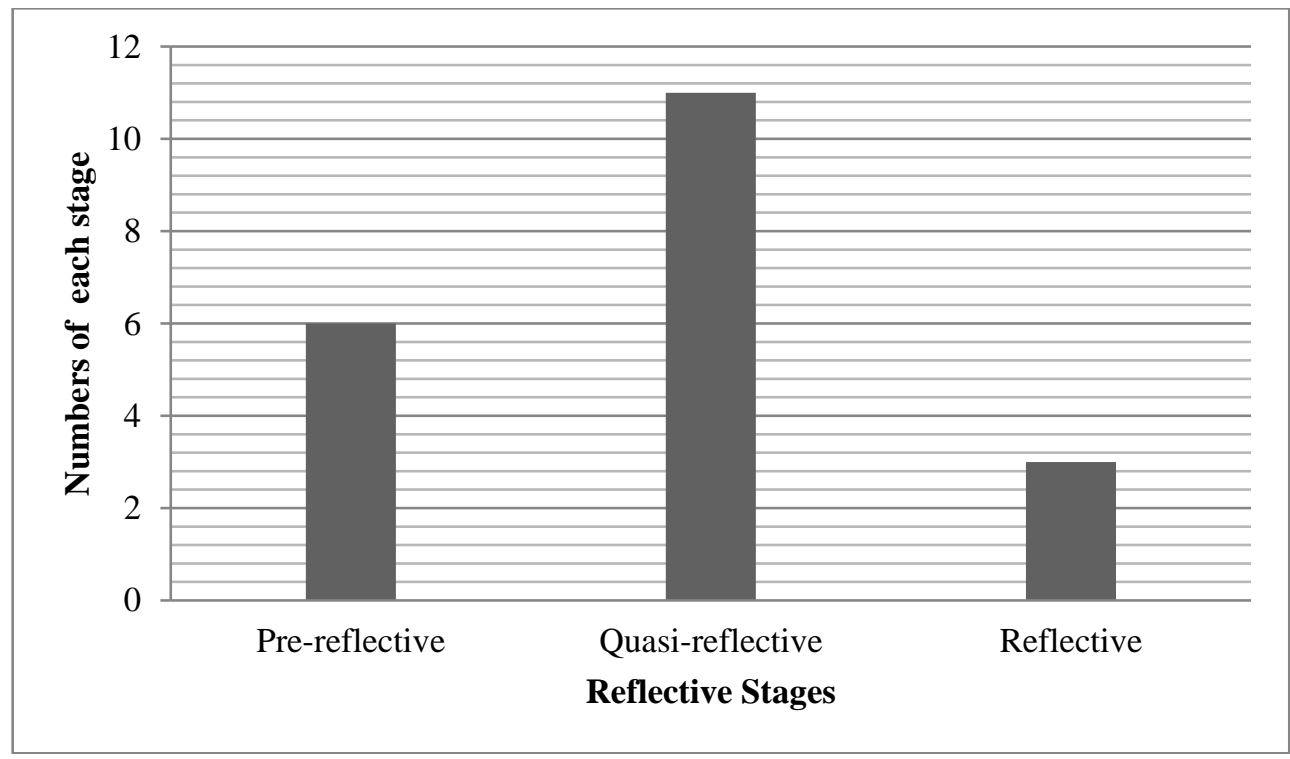

Figure 1. Numbers of Pre, Quasi, and Reflective Stages: Food Additives Issue

Following dialogues are direct quotations from semi-structured interviews.

What is your opinion about food colorings?

Foods seem enjoyable and attractive when we use food colorings those attracts consumer. Although there are some regulations for using food colorings, different bodies may have different reactions to them. They can be dangerous, or they can cause allergic reactions. (Stage 5) 
Researchers' rationale: She has subjective interpretation for using food colorings. She evaluates both side of the issue (attractive- allergic reactions). She is uncertain about using food colorings.

\section{Can you ever for sure that your position is correct?}

I am not sure. I made a comment with my own experience; however, a food engineer can claim that it may cause health problems, but this is also a claim that should be supported. We cannot be sure whether the allergic reaction happened because of the additives or not. (Stage 5)

Researchers' rationale: She is aware of that she has subjective interpretation about the issue. She takes food engineers as authority, but she does not think that they are the source of right answers. She sees authorities as experts but knows that knowledge is limited to experts own perspectives.

\section{Alternative Energy Sources}

Following the food additives issue, alternative energy sources were examined. Efficiency of solar energy, wind turbines, thermal energy, and hydroelectric power plants activities were completed at this week. Figure 2 shows the number of pre-reflective, quasi-reflective, and reflective stages appeared in the alternative energy sources experiment.

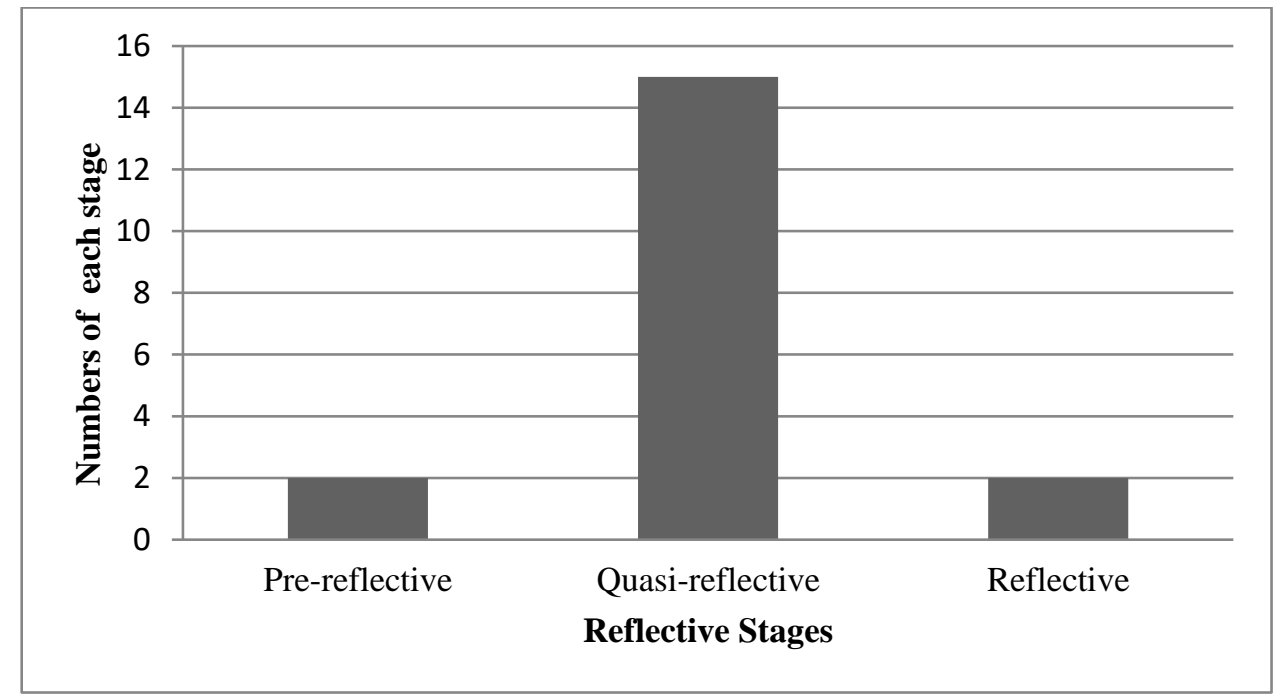

Figure 2. Numbers of Pre, Quasi, and Reflective Stages: for Energy Issue

The dominant stage observed in energy week was quasi-reflective stage. Fifteen quasi-reflective stage, two pre-reflective, and two were reflective stages were observed. Nineteen report were assessed at this week due to the absence of one PT.

\section{The Climate Change Issue}

Pre-service teachers attempted to explore numerous effects of climate change which are; the effects of acid rain, greenhouse effect, and sea level rise and its effects to the environment.

Climate change was a controversial issue for participants. Some of them were sure that people caused recent climate changes; However, some of them argued that it is a normal process which has happened 
in the past and will happen in future. Figure 3 shows the numbers of pre-reflective, quasi-reflective and reflective stages for the climate change experiments.

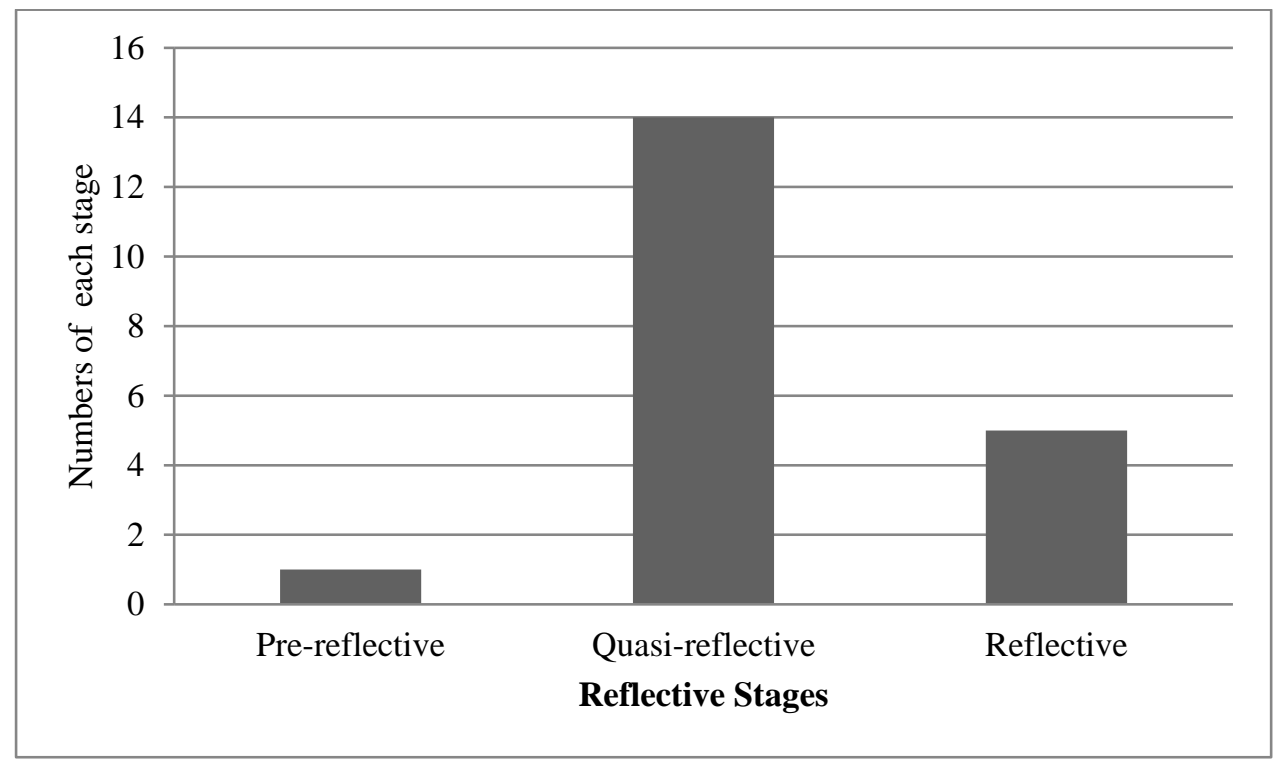

Figure 3. Numbers of Pre, Quasi and Reflective Stages: The Climate Change Issue

Quasi-reflective stages were frequently observed across climate change week. There were fourteen quasi-reflective stage, one pre-reflective, and five reflective stages. Some example dialogues were quoted in following paragraphs.

\section{What do you think about the climate change issue?}

I think some scientists are exaggerating the climate data. You know; Al Gore's Nobel prize has been cancelled because his work was ruled politically biased and containing scientific errors. But personally I experience some climate change problems, there are IPCC data. I think; the climate is changing but maybe this change is a little bit exaggerated. (Stage 6)

Researcher rationale: The student is aware of the problem. She evaluates the issue from both (negative and positive) aspects. She tries to construct her knowledge by depending on various sources.

On what do you base your point of view?

I read lots of articles; we watched national geographic documentaries in class; there are lots of protocols, such as Kyoto. You know the amount of $\mathrm{CO} 2$ increase, sea level rise. I mean; the nature is unbalanced know.

Researchers' rationale: Knowledge is based on information from a variety of sources. (Articles, Documentaries, International Protocols, IPCC data, and her personal opinion)

\section{The Industrial Revolution}

The effects of Industrial Revolution on society were examined last week of the investigation. Soil pollution, air pollution and water pollution occurred during industrialization were tested. Figure 4 shows the numbers of pre-reflective, quasi-reflective and reflective stages appeared in the Industrial Revolution issue experiments. In this laboratory, the number of reflective judgment scores slightly increased. However, quasi reflective stage was still dominant. 


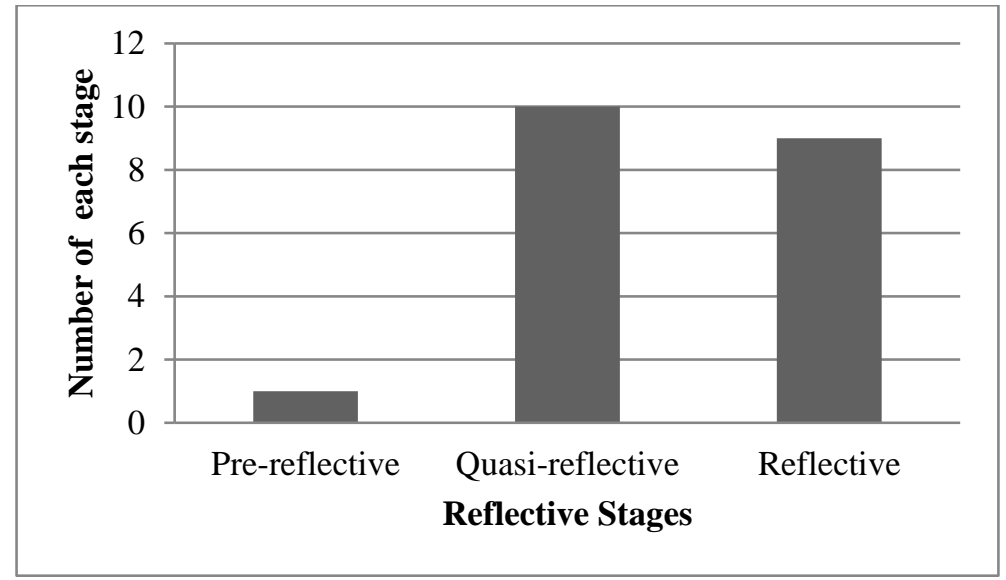

Figure 4. Numbers of Pre, Quasi and Reflective Stages: Industrial Revolution

\section{Three digit scores of each preservice teacher across four SSI.}

Preservice teachers' reflective judgment stages were assessed across four SSI contexts. Table 2 provides the three-digit scores of individuals' reflective judgment over the four socio-scientific issues Twenty laboratory reports and semi-structural interviews on the same issue were analyzed regularly each week and preservice teachers' written responses and oral responses were compared to triangulate the results. Results were categorized into one of the three broad domains of reflective judgment: pre-reflective, quasi-reflective and reflective.

Table 2

Summary of Reflective judgment scores across related SSI contexts.

\begin{tabular}{lllll}
\hline Pre-service Teacher & Food & Energy & Climate & Industrial Revolution \\
\hline 1 & $5-5-6$ & $5-5-6$ & $3-4-5$ & $4-4-5$ \\
2 & $1-1-2$ & incomplete & $5-5-5$ & $5-5-6$ \\
3 & $5-5-6$ & $6-6-5$ & $6-6-5$ & $5-5-6$ \\
4 & $5-5-4$ & $5-6-6$ & $2-2-3$ & $5-5-5$ \\
5 & $6-6-5$ & $5-5-5$ & $5-5-6$ & $5-5-5$ \\
6 & $5-5-4$ & $5-5-4$ & $5-5-6$ & $5-5-6$ \\
7 & $5-5-4$ & $5-5-6$ & $5-5-5$ & $6-6-5$ \\
8 & $6-6-7$ & $5-5-4$ & $4-4-3$ & $6-6-7$ \\
9 & $5-5-4$ & $5-5-4$ & $5-5-6$ & $6-6-5$ \\
10 & $3-3-2$ & $4-4-5$ & $5-5-6$ & $6-6-6$ \\
11 & $5-5-4$ & $2-2-1$ & $5-5-4$ & $4-4-4$ \\
12 & $5-5-4$ & $5-5-4$ & $6-6-5$ & $6-6-7$ \\
13 & $4-4-5$ & $1-1-3$ & $5-5-5$ & $5-5-5$ \\
14 & $5-5-6$ & $5-5-6$ & $4-4-6$ & $6-6-6$ \\
15 & $1-1-4$ & $6-6-5$ & $5-5-4$ & $5-5-6$ \\
16 & $1-1-2$ & $5-5-5$ & $6-6-5$ & $5-5-6$ \\
17 & $6-6-7$ & $5-5-6$ & $5-5-6$ & $6-6-6$ \\
18 & $3-3-5$ & $5-5-5$ & $5-5-6$ & $3-3-3$ \\
19 & $3-6-5$ & $6-6-7$ & $6-6-5$ & $6-6-6$ \\
20 & $1-1-1$ & $5-5-6$ & $6-6-7$ & $5-5-6$ \\
\hline
\end{tabular}

Table 2 illustrates that preservice teachers' three digit scores tended to increase from the first experiment to the last (e.g., Pre-service teacher 10 was rated 3-3-2 for the first issue and 6-6-6 for the last issue). It can be referred from Table 2 that quasi reflective stage was dominant across all weeks. For the food additives weeks three responses were labelled as pre-reflective which belonged to Pre-service teachers $2,10,15,16,18$ and 20 . As it was explained in data analysis procedure in detail, each digit was differentially weighted (50\% for the first digit, $30 \%$ for the second, $20 \%$ for the $3^{\text {rd }}$ digit) to reflect the relative proportion of emphasis given to the particular developmental levels. Thus, Pre-service teacher 
15 's calculated score was $[(1 \times 0.5)+(1 \times 0.3)+(4 \times 0.2)=1.6]$ in pre-reflective stage (i.e., the original score was 1-1-4, although 4 is in the range of quasi reflective stage, dominant stages were 1-1). For the alternative energy week only two responses labelled as pre-reflective which belonged to Pre-service teacher 11 and 13. The numbers of the pre-reflective responses decreased in following weeks. Preservice teacher 4 and 18 were labelled as pre-reflective for climate change and the industrial revolution issue respectively. Table 3 shows the frequencies for reflective judgment stages across each week.

Table 3

Frequencies for Reflective judgment Domains across SSI.

\begin{tabular}{lllll}
\hline RJM Domains & Food additives & Alternative Energy & Climate change & Industrial Revolution \\
\hline Pre-reflective & 6 & 2 & 1 & 1 \\
Quasi-reflective & 11 & 15 & 14 & 10 \\
Reflective & 3 & 2 & 5 & 9 \\
\hline
\end{tabular}

As Table 3 suggest that the number of the PTS responses found in the pre-reflective domain decreased from food additives issue $(n=6)$ to industrial revolution issue $(n=1)$, while the number of the responses for the reflective domain increased from food additive issue $(n=3)$ to the industrial revolution issue $(n=9)$ throughout the semester. However, this is not true for all issues, as individuals' scores for each issue varied from context to context. For example, it can be noted that there was a sharp decrease in participant 13's reflective judgment score for the alternative energy issue (1-1-3), and a decrease in participant 4's reflective judgment score (2-2-3) for the climate change issue.

\section{DISCUSSION}

Much SSI research and classroom pedagogy tend to be focused on the kinds of reasoning strategies students evoke during discussions that occur in classroom settings, but generally apart from laboratory investigations. Our aim was to explore pre-service teachers' reflective judgment skills in SSI based inquiry science laboratory. Findings of the current study illustrated that majority of the Pre-service teachers' responses were in quasi-reflective stage. Undergraduate students' reflective judgment abilities have been studied in prior research (King \& Kitchener, 1994; Kitchener \& King, 1981; Wood, Kitchener, \& Jensen, 2002) and typically, most students were observed to be in the quasi-reflective stage, as well. In the present study, results showed that at the beginning of the semester some preservice teachers were at the pre-reflective stage and very few of them were at the reflective stage. By the end of the semester, however, the number of the pre-reflective stage responses decreased, while the quasireflective and reflective stage responses increased. Since this shift among the stages was subtle, it suggests that changing students' reflective judgment is a gradual developmental process. This finding is in agreement with Kitchener, Lynch, Fischer, and Wood (1993) who suggest that those reflective judgment skills of individuals would tend to gradually but slowly increase over shorter periods of time. King and Kitchener (2004) highlighted that the amount of change was smallest in studies of short duration (3-4 months). King, Kitchener, and Wood (1994) also reported that charting substantial changes in individuals' reflective judgment requires longitudinal data. Zeidler, et al. (2009) also confirmed that students should be engaged in a semester long SSI course in order to see any improvement in their reflective judgment skills. Thus, based on the findings of this study and the results of the earlier studies stated above, longer exposure to classroom learning experiences regarding reflective judgment can be regarded to result in better facilitation of students obtaining higher levels of reflective judgment.

The findings of the current study enabled us to interpret the role of the context in students' reflective judgment. Although the overall RJM scores tended to increase from the first experiment to last 
experiment (i.e., number of reflective preservice teachers increased from three to nine) there were no temporal linear increase/decrease on individual scores. Given that this research only extended over the course of one academic semester, and given the age of the college students, it is plausible that this shift has less to do with developmental factors and more to do with differential performance across contextual SSI factors. Variation of the reflective judgment across different contexts has also been addressed in previous studies (e.g., Kitchener et. al., 1993; King \& Kitchener, 2002; Rest, 1979). Findings are also supportive of the research on differential reasoning patterns in varied SSI contexts for both intellectual and affective domains (Bell \& Lederman, 2003; Sadler, Chambers, \& Zeidler, 2004; Zeidler et al., 2013). This interpretation is consistent with Fischer's (1980) assertion that "skills in a context" (i.e., the strength of the skill) can be variable and situational, changing as circumstances, time of day, or emotional stage changes. Therefore, it is more prudent to be sensitive to how contextual differences on SSI affect performance in terms reflective judgment within restrictive developmental period of time.

It is worth noting a developmental caveat - that is, characterizing individuals as being "in" or "at" a single stage, can be misleading. Kitchener et al., (1993) attribute individuals' score variations across different contexts to the motivation or personal interest connected to a particular situation or issue. In the present study, the expressed variation in preservice teachers' reflective judgment across different socio-scientific issues could reasonably be attributed to the particular characteristics of the issues and preservice teachers' motivation to engage in a domain of interest (e.g., climate change, alternative energy, etc.).

\section{CONCLUSION}

As it is stressed in the beginning of this paper, this research was guided from a sociocultural perspective that places precedence on thinking, reasoning and engaging the participants in science activities rather than memorization of knowledge and processes. If educators wish for school science to be meaningful to the lives of children, then it must be situated in contexts that provide opportunities for reflective, discussion and collective evidence-based decisions. Moreover, if science educators are passionate about improving science education, then the quality of the educative experience of teacher education programs must be commensurate with those aims. Students in teacher education programs need to experience teaching socio-scientific issues so that they can better equipped themselves to teach them to their future students through student-centered implementations. This study provided information in terms of how to integrate SSI within science laboratory settings. Results of the study suggests that exploring Reflective Judgment in SSI contexts is beneficial for allowing preservice teachers to actively engage in knowledge construction during classroom discussions.

Finally, it is noteworthy that if an SSI directly connected to the students' lives, it appeared to initiate and sustain students' curiosity, promote active engagement and personal involvement. This suggests that it is important to consider the contextual factors that may play important role in designing curricular experiences, whereby student are better able to engage themselves in a given issues by using their cognitive, affective, and psychomotor skills. Students' familiarity and interest in socio-scientific issues may be improved by triggering their reflective judgment skills and argumentation.

\section{Acknowledgement}

This study is part of $\mathrm{PhD}$ thesis of the first author completed at Middle East Technical University, under the advice of second author and co-advice of third author. 


\section{REFERENCES}

Anderson, R. D. (2002). Reforming science teaching: What research says about inquiry. Journal of Science Teacher Education, 13(1), 1-12.

Aydın, F. (2014). Ortaöğretim öğrencilerinin küresel ısınma konusundaki bilgi düzeylerinin belirlenmesi. Turkish Journal of Education, 3(4), 15-27. DOI: 10.19128/turje.181089

Bell, R.L., \& Lederman, N. G. (2003). Understandings of the nature of science and decision making on science and technology based issues. Science Education, 87(3), 352-377.

Bybee, R. W. (2000). Teaching science as inquiry. In, J. Minstrel \& E. H. Van Zee (Eds), Inquiring into inquiry learning and teaching in science (pp. 20-46). Washington, DC: AAAS.

Chistenson, N., Chang-Rundgren, S. N., \& Zeidler, D.L. (2014). The relationship of discipline background to upper secondary students' argumentation of socio-scientific issues. Research in Science Education, 44(4), 581-601.

Crawford, B. A. (2000). Embracing the essence of inquiry: New roles for preservice teachers. Journal of Research in Science Teaching, 37(9), 916-937.

Cobern, W. W., Schuster, D., Adams, B., Applegate, B., Skjold, B., Undreiu, A., \& Gobert, J. D. (2010). Experimental comparison of inquiry and direct instruction in science. Research in Science \& Technological Education, 28(1), 81-96.

Dewey, J. (1938). Logic: The theory of inquiry. New York: Peter Lang Publishing.

Domin, D. S. (1999). A review of laboratory instruction styles. Journal of Chemical Education, 76(4), 543-547.

Eastwood, J. L., Sadler, T. D., Zeidler, D. L., Lewis, A., Amiri, L., \& Applebaum, S. (2012). Contextualizing nature of science instruction in socioscientific issues. International Journal of Science Education, 34(15), 2289-2315.

Egan, K., Cant, A., \& Judson, G. (Editors) (2014). Wonder-full education: the centrality of wonder in teaching and learning across the curriculum. New York, NY: Routledge.

Eş, H., Mercan, S. I., \& Ayas, C. (2016). Türkiye için yeni bir sosyo-bilimsel tartışma: Nükleer ile yaşam. Turkish Journal of Education, 5(2), 47-59.

Evagorou, M., \& Mauriz, B. P. (2017). Engaging elementary school pre-service teachers in modeling a socioscientific issue as a way to help them appreciate the social aspects of science. International Journal of Education in Mathematics, Science and Technology, 5(2), 113-123.

Fischer, K. W. (1980). A theory of cognitive development: The control and construction of hierarchies of skills. Psychological Review, 87(6), 477-531.

Flavell, J. (1977). Cognitive development. Englewood Cliffs, NJ: Prentice-Hall.

Fowler, S. R., Zeidler, D. L., \& Sadler, T. D. (2009). Moral sensitivity in the context of socioscientific issues in high school science students. International Journal of Science Teacher Education, 31(2), 279-296.

Green, W. J., Elliott, C. \& Cummins, R. H. (2004). Prompted inquiry-based learning in the introductory chemistry laboratory. Journal of Chemical Education, 81(2), 239-241.

Kegan, R. (1982). The evolving self. Cambridge, MA: Harvard University Press.

Khishfe, R. (2015). A Look into students' retention of acquired nature of science understandings. International Journal of Science Education, 37(10), 1639-1667.

Klosterman, M. L., \& Sadler, T. D. (2010). Multi-level assessment of scientific content knowledge gains associated with socioscientific issues-based instruction. International Journal of Science Education, 32(8), 10171043.

King, P. M., \& Kitchener, K. S. (1994). Developing reflective judgment: Understanding and promoting intellectual growth and critical thinking in adolescents and adults. San Francisco, CA: Jossey- Bass.

King, P. M., \& Kitchener, K. S. (2002). The reflective judgment model: Twenty years of research on epistemic cognition. In B. K. Hofer \& P. R. Pintrich (Eds.), Personal epistemology: The psychology of beliefs about knowledge and knowing, (pp. 37-61). Mahway, NJ: Lawrence Erlbaum.

King, P. M., \& Kitchener, K. S. (2004). Reflective judgment: Theory and research on the development of epistemic assumptions through adulthood. Educational Psychologist, 39(1), 5-18.

King, P., Kitchener, K. S., \& Wood, P. K. (1994). Research on the reflective judgment model. In P. M. King \& K. S. Kitchener (Eds.), Developing reflective judgment: Understanding and promoting intellectual growth and critical thinking in adolescents and adults. (pp 124- 188). San Francisco, CA: Jossey-Bass.

Kirschner, P. A., Sweller , J., \& Clark, R. E. (2006). Why minimal guidance during instruction does not work: An analysis of the failure of constructivist, discovery, problem-based, experiential, and inquiry-based teaching. Educational Psychologist, 41(2), 75-86.

Kitchener, K. S., \& King, P. M. (1981). Reflective judgment: Concepts of justification and their relationship to age and education. Journal of Applied Developmental Psychology, 2(2), 89-116. 
Kitchener, K. S., Lynch, C. L., Fischer, K. W., \& Wood, P. K. (1993). Developmental range of reflective judgment: The effect of contextual support and practice on developmental stage. Developmental Psychology, 29(5), 893.

Kolstø, S. D. (2001). Scientific literacy for citizenship: tools for dealing with controversial socio-scientific issues. Science Education, 85(3), 291-310.

Lee, H., Chang, H., Choi, K., Kim, S. W., \& Zeidler, D. L. (2012). Developing character and values for global citizens: Analysis of pre-service teachers' moral reasoning on socioscientific issues. International Journal of Science Education, 34(6), 925-953.

Lee, Y. C., \& Grace, M. (2012). Students' reasoning and decision making about a socioscientific issue: A crosscontext comparison. Science Education, 96(5), 787-807. DOI: 10.1002/sce.21021.

Lee, H., Yoo, J., Choi, K., Kim, S., Krajcik, J., Herman, B., \& Zeidler, D. L. (2013). Socioscientific Issues as a Vehicle for Promoting Character and Values for Global Citizens. International Journal of Science Education, 35(12), 2079-2113.

Lincoln, Y. S., \& Guba, E. G. (1985). Naturalistic inquiry. Beverly Hills, CA: Sage.

Liu, S. Y., Lin, C. S., \& Tsai, C. C. (2011). College students' scientific epistemological views and thinking patterns in social scientific decision making. Science Education, 95(3), 497-517.

Maulucci, M. S. R. (2010). Invoking the sacred: reflections on the implications of Ecojustice for science education. In D. Tippins, M. Mueller, M. van Eijck \& J. Adams (Eds.), Cultural studies and environmentalism: The confluence of ecojustice, place-based (science) education, and indigenous knowledge systems (pp. 43-49). New York: Springer.

MacFarlane, B. (2001). Developing reflective students: Evaluating the benefits of learning logs within a business ethics program. Teaching Business Ethics, 5(4), 375-387.

Martín-Gámez, C., \& Erduran, S. (2018). Understanding argumentation about socio-scientific issues on energy: a quantitative study with primary pre-service teachers in Spain. Research in Science \& Technological Education, 1-21.

Merriam, S. B. (2009). Qualitative Research: a guide to design and interpretation. San Francisco: Jossey-Bass.

National Research Council. (2012). National science education standards. National Academy Press, Washington, DC. 262.

Next Generation Science Education Standards (2012). Next Generation Science Education Standards: For States, By States. Washington, DC: The National Academies Press.

Nielsen, G. M. (2012). The norms of answerability: Social theory between Bakhtin and Habermas. New York, NY: SUNY Press.

Osborne, J., \& Dillon, J. (2008). Science education in Europe: Critical reflections. London: The Nuffield Foundation.

Paris, S. G., \& Ayres, L. R. (1994). Becoming reflective students and teachers with portfolios and authentic assessment. Washington, DC: American Psychological Association.

Perry, W. G. Jr. (1981). Cognitive and ethical growth: The making of meaning. In A.W. Chickering et al. (Eds.). The modern American college: Responding to the new realities of diverse students and a changing society. San Francisco: Jossey-Bass.

Piaget, J. (1974). Stages of intellectual development in the child and adolescent. In J. Piaget (Ed.). The child and reality (A. Rosin, Trans.). New York: Viking.

Rest, J. (1979). Development in judging moral issues. Minneapolis, MN: University of Minnesota Press.

Sadler, T. D. (2004). Moral and ethical dimensions of socioscientific decision-making as integral components of scientific literacy. The Science Educator, 13(1), 39-48.

Sadler, T. D., Chambers, F. W., \& Zeidler, D. L. (2004). Student conceptualizations of the nature of science in response to a socioscientific issue. International Journal of Science Education, 26(4), 387-409.

Stake, R. E. (1995). The art of case study research. Thousand Oaks, CA: Sage Publications.

Waight, N., \& Abd-El-Khalick, F. (2011). From scientific practice to high school science classrooms: Transfer of scientific technologies and realizations of authentic inquiry. Journal of Research in Science Teaching, 48(1), 37-70.

Wood, P.K., Kitchener, K.S., \& Jensen, L. (2002). Considerations in the design and evaluation of a paper-and pencil measure of reflective thinking. In B. Hofer and P. Pintrich (Eds.), Personal epistemology: The psychology of beliefs about knowledge and knowing. Mahwah, NJ: Lawrence Erlbaum Associates.

Yoonsook, C., Yoo, J., Kim, S-W., Lee, H., \& Zeidler, D. L. (2016). Enhancing students' communication skills in the science classroom through socioscientific issues. International Journal of Science and Mathematics Education, 14(1), 1-27.

Zeidler, D. L. (2014). Socioscientific issues as a curriculum emphasis: Theory, research and practice. In N. G.

Lederman \& S. K. Abell (Eds.), Handbook of research on science education, Volume II (pp. 697-726). New York, NY: Routledge. 
Zeidler, D. L., Herman, B., Ruzek, M., Linder, A. \& Lin, S. S. (2013). Cross-cultural epistemological orientations to socioscientific issues. Journal of Research in Science Teaching, 50(3), 251-283.

Zeidler, D.L., \& Kahn, S. (2014). It's debatable: Using socioscientific issues to develop scientific literacy, K-12. Arlington, VA: National Science Teachers Association Press.

Zeidler, D. L., \& Sadler, T. D. (2008). The role of moral reasoning in argumentation: Conscience, character and care. In S. Erduran \& M. Pilar Jimenez-Aleixandre (Eds.), Argumentation in science education: Perspectives from classroom-based research (pp. 201-216). The Netherlands: Springer Press.

Zeidler, D. L., Sadler, T. D., Applebaum, S., \& Callahan, B. E. (2009). Advancing reflective Judgment through socioscientific issues. Journal of Research in Science Teaching, 46(1), 74-101.

Zeidler, D. L., Sadler, T. D., Simmons, M. L., \& Howes, E. V. (2005). Beyond STS: a research-based framework for socioscientific issues education. Science Education, 89(3), 357-377. 


\section{TÜRKÇE GENIŞLETILMIŞ ÖZET}

Bilim ve teknoloji çağımızın vazgeçilmez unsurlarındandır. 21. Yüzyıl bilim ve teknoloji alanındaki hızlı değişim/gelişimler ile anılmaktadır. Bu gelişmelerin insan hayatını kolaylaştırdığı, seri üretime katkı sağladığı, ulaşım, iletişim, yeme-içme, giyim gibi birçok alana etki ettiği bilinmektedir. Ancak bu gelişmelerin direkt ve dolaylı etkilerinin her zaman toplum yararına olduğu söylenemez. Bilim ve teknolojideki bu gelişmelerin toplum hayatına olan olumlu olumsuz etkileri sosyo-bilimsel konular (SBK) bağlamında incelenmektedir. Sosyo-bilimsel konuların bireylerin araştırma, inceleme ve bilgiyi aktif olarak değerlendirmelerine imkân tanıdığı ve bu sayede de fen okuryazarlığına katkı sağladığı bilinmektedir. Fen eğitiminin öncelikli amaçlarından biri de fen okuryazarı bireyler yetiştirmektir. Bu bireyler fennin günlük hayattaki yansımalarını bilir, fen ve teknolojinin avantaj ve dezavantajlarını kavrar ve bilim temelli sorunları değerlendirirken çok yönlü ele alırlar. Bireylerin fen okuryazarı olarak yetişmelerini sağlamak amacı ile önerilen yöntemlerden biri de derslerde sosyo-bilimsel konulara yer verilmesidir. Bu konular sayesinde öğrencilerin bilim, teknolojinin ve toplum arasındaki etkileşimi çok yönlü ele almalarını sağlanmakta, etkileşimleri etik ve ahlaki açılardan değerlendirmelerine olanak verilmektedir. $\mathrm{Bu}$ noktalardan hareketle bu çalışmada öğretmen adaylarının SBK temelli fen öğretiminde laboratuvar uygulamaları dersindeki yansıtıcı muhakeme becerilerini incelemektir.

Çalışma nitel durum çalışmadır. Katılımcılar, araştırma odaklı bir devlet üniversitesinde öğrenim görmekte olan 20 öğretmen adayından oluşmaktadır. Öğretmen adaylarının yansıtıcı muhakeme becerilerini ortaya çıkarmak amacı ile dört farklı sosyo-bilimsel konu seçilmiştir. Bu konular; gıda katkı maddeleri, alternatif enerji kaynakları, iklim değişimi ve endüstri devrimidir. Her bir konu dört saatlik ders süresince tartışılmış, tartışma sonunda öğretmen adaylarından konu ile ilgili araştırmak istedikleri bir problem cümlesi belirlemeleri istenmiştir. Öğretmen adayları kendi belirledikleri araştırma problemlerini kendi tasarladıkları deneylerle cevaplamaya çalışmışlardır. Deney raporları içerisine entegre edilen 7 adet "Yansitıcı Muhakeme Modeli Mülakat Soruları" (Prototypic Reflective Judgment Interview Questions) ile öğretmen adaylarının yansıtıcı muhakeme becerileri ortaya çıkartılmaya çalışılmıştır. Bu sorular standart olup (örnek: ..... hakkında ne düşünüyorsun? Bu düşünceye nasıl eriştin? Bu bakış açısını neye dayandırırsın? Bu konudaki tutumunuzun doğruluğundan emin olabilir misin? Bu tür tartışmalı konularda iki kişi birbirine zıt fikirlere sahipse bir tanesi doğru diğeri yanlış diyebilir miyiz? vb.) her deney raporu sonuna eklenmiştir. Deney raporlarına verilen yazılı cevaplar, yarı yapılandırılmış görüşmelerle teyit edilerek veri çeşitlemesi yapılmıştır.

Veriler King ve Kitchener (1994) tarafından önerilen Reflektif Muhakeme Modeli teorik çerçevesi referans alınarak betimsel olarak analiz edilmiştir. Bu modele göre muhakeme becerileri üç seviyede ele alınmıştır. Birinci seviye (pre-reflective) basit düzey muhakemelere karşılık gelmektedir. Bu seviye için puan aralığ 1-3 arasındadır. İkinci seviye (quasi-reflective) orta düzey yansıtıcı muhakemelere karşılık gelmektedir. Orta düzey muhakemeye sahip bireyler birinci düzeydekiler kadar değişmez yargılara sahip değillerdir ancak üçüncü düzeydekiler kadar üst düzey muhakeme becerisine de sahip değildirler. Bu seviye için puan aralı̆̆ 1 4-5 arasındadır. Son seviye (reflective) tam anlamı ile yansitıcı muhakeme becerilerine sahip bireylerin özelliklerini içermektedir. Bu seviye için puan aralığı 6 ve 7'dir. Teorik çerçeve dikkatle incelendiğinde bireylerin tek bir seviyede sabit görüşler bildirmelerinin mümkün olmadığı, farklı konularda farklı seviyelere ait puan alabilecekleri görülmektedir. Bu yüzden analiz yapılırken öğretmen adaylarının her bir soruya verdikleri cevaplar bağımsız olarak incelenmiş ve puanlanmıştır. Son puanlar hesaplanırken en sık karşılaşılan üç puan ard arda yazılmış (örn. 1-1-4) ilk puanın yüzde ellisi, ikinci puanın yüzde otuzu, son puanın yüzde yirmisi alınarak hesaplama yapılmışıı ve öğretmen adayları bu son puana göre 1. Seviye, 2. Seviye ya da 3. Seviye muhakeme becerisine sahiptir diye belirtilmiştir.

Gıda katkı maddeleri konusunda verilen cevaplar incelendiğinde 1. Seviyede alt1, 2. Seviyede 11, 3. Seviyede ise üç öğretmen adayı olduğu görülmüştür. Alternatif enerji konusu için bu değerler sırası ile iki, 15 ve ikidir. İklim değişikliği konusu için bir, 14 ve beş; Endüstri devrimi konusunda ise bir, 10 ve 
dokuz bulunmuştur. Bu sonuçlara göre öğretmen adaylarının Yansıtıcı Muhakeme Modeli puanlarının birinci deneyden son deneye doğru gelişme gösterdiği görülmektedir. Sonuçlar incelendiğinde 3. Seviyedeki birey sayısı 3 ten 9'a yükselirken, 1. Seviyedeki birey sayısının 6 dan 1'e düştüğü görülmektedir.

Genel olarak dört konuda da 2. seviye muhakeme (quasi-reflective) becerisine sahip bireylerin fazla olduğu görülmektedir. Bu bulgu alan yazında da lisans öğrencilerinin genel olarak sahip olduğu yansıtıc1 muhakeme düzeyi olarak görülmektedir. King ve Kitchener (1994) yapmış oldukları 20 yıllık çalışmanın sonucunda lisans öğrencilerinin genelinin 2. Seviye (quasi-reflective) yansıtıcı muhakeme yaptıklarını bulmuşlardır. Özet olarak, sosyo-bilimsel konular öğretmen adaylarının yansıtıcı muhakeme becerilerini ortaya çıkarma konusunda faydalı olmuştur. 